\title{
POGIL Berpengaruh terhadap Kemampuan Berpikir Kritis Matematis?
}

\author{
Erlin Prihatami \\ Program Studi Pendidikan Matematika, Universitas Muhammadiyah Purwokerto \\ prihatamierlin97@gmail.com
}

\begin{abstract}
ABSTRAK
Kemampuan berpikir kritis merupakan salah satu kemampuan yang harus dimiliki siswa dalam pembelajaran matematika, sehingga siswa mampu mengambil keputusan yang tepat saat memecahkan masalah matematis. Penelitian ini bertujuan untuk menganalisis bagaimana pengaruh POGIL terhadap kemampuan berpikir kritis matematis siswa. Jenis penelitian yang digunakan adalah penelitian eksperimen semu, dengan desain penelitian post test only control design. Populasi pada penelitian ini adalah seluruh siswa kelas VIII SMP N 2 Kemangkon tahun pelajaran 2018/2019, dengan pengambilan sampel menggunakan teknik cluster random sampling dan diperoleh dua kelas sampel yaitu kelas VIII C sebagai kelas eksperimen yang menggunakan pembelajaran dengan model POGIL dan kelas VIII B sebagai kelas kontrol yang menggunakan model pembelajaran konvensional. Instrumen yang digunakan pada penelitian ini adalah post test kemampuan berpikir kritis matematis. Setelah memenuhi uji prasyarat, yaitu normalitas dan homogenitas, dilakukan uji hipotesis menggunakan independent sample t-test dengan tingkat kepercayaan 95\%. Berdasarkan hasil uji hipotesis, disimpulkan bahwa POGIL berpengaruh terhadap kemampuan berpikir kritis matematis siswa kelas VIII SMP N 2 Kemangkon.
\end{abstract}

Kata kunci: Kemampuan Berpikir Kritis matem\#atis, Process Oriented Guided Inquiry Learning (POGIL)

\begin{abstract}
Critical thinking is one of the skills students must have in mathematics learning so that students can make the right decisions when solving mathematical problems. This study aims to analyze the effects of the POGIL on students' mathematical critical thinking skills. This research is an quasy experimental study, with a post test only control design research design. The population in this study were all students of grade VIII SMP N 2 Kemangkon in the academic year of 2018/2019. The sampling was done by cluster random sampling techniques and it obtained two sample classes namely class VIII C as an experimental class using learning with the POGIL model and class VIII B as control class using conventional learning models. The instrument used in this study was post-test mathematical critical thinking skill. Based on the result of hypothesis testing using independent sample t-test with a 95\% confidence level, it shows that POGIL has an effect on students' mathematical critical thinking skills.
\end{abstract}

Key words: Mathematical Critical Thinking Skills, Process Oriented Guided Inquiry Learning (POGIL)

\section{Pendahuluan}

Matematika termasuk ilmu yang penting dalam perkembangan tekhnologi, sains, dan pengembangan daya fikir logis, analitis, sistematis, kritis, dan juga kreatif, sehingga matematika perlu diberikan kepada semua peserta didik mulai dari sekolah dasar untuk membekali diri mereka dengan kemampuan berpikir yang baik (Fahmy, Wardono, \& Masrukan, 2018). Pentingnya matematika dapat dilihat dari perannya sebagai prediktor bagi 
anak-anak yang memasuki sekolah formal, bahkan di masa teknologi dan digital saat ini matematika hampir berperan pada segala aspek (Siregar, 2017).

Salah satu kemampuan yang dibutuhkan dalam matematika adalah kemampuan berpikir kritis matematis. Johnson (2007) dan Haryani (2011) mengemukakan berpikir kritis matematis adalah proses yang bertujuan untuk membuat keputusan rasional dalam memecahkan masalah, mengambil keputusan, membujuk, menganalisis asumsi, dan dilakukan secara terus menerus, aktif, dan teliti. Penting bagi siswa memiliki kemampuan berpikir kritis matematis, agar siswa dapat menyalurkan pemikiran mereka sendiri serta menerapkan pengetahuan sebelumnya dengan pengetahuan yang diperolehnya. Siswa yang tidak dilatih untuk memiliki kemampuan berpikir kritis matematis akan cenderung sulit mengambil suatu keputusan dari suatu permasalahan yang menyebabkan siswa sulit memecahkan masalah dalam kehidupan sehari-hari (Prihatiningsih, dkk, 2016).

Berpikir kritis matematis merupakan suatu proses penggunaan kemampuan berpikir secara rasional dan reflektif yang bertujuan atau beralasan untuk mengambil keputusan tentang apa yang diyakini atau dilakukan (Ennis, 1991; Ennis, 2011). Menurut Paul dan Linda (2007) berpikir kritis matematis adalah proses menganalisis dan menilai pemikiran dengan pandangan untuk memperbaiki. Kemampuan berpikir kritis matematis merupakan proses mencari, memperoleh, mengevaluasi, menganalisis, menyinkronkan, dan mengonseptualisasikan informasi sebagai panduan untuk mengembangkan pemikiran seseorang dengan kesadaran diri, dan kemampuan untuk menggunakan informasi ini dengan menambahkan kreativitas dan mengambil risiko (Yildirm \& Ozkahraman, 2011).

Adapun indikator yang digunakan dalam penelitian ini adalah 1) menganalisis, siswa dapat menguraikan permasalahan menjadi apa yang diketahui, apa yang ditanyakan, dan mengidentifikasinya dalam sebuah diagram, memilah, dan mengurutkan informasi yang diperlukan dalam menyelesaikan masalah; 2) mensintesis, siswa dapat menggabungkan informasi dari permasalahan menjadi konsep yang utuh, sehingga dapat digunakan untuk menyelesaikan masalah yang ada; 3) menyimpulkan, siswa dapat memberi kesimpulan atas suatu jawaban; dan 4) mengevaluasi, siswa mampu menilai benar atau salah dari suatu permasalahan serta dapat membuktikannya.

Berdasarkan hasil wawancara dengan guru matematika, menunjukkan beberapa permasalahan dimana siswa cenderung tidak percaya diri ketika di persilahkan untuk maju mengerjakan soal di papan tulis dan mengemukakan pendapat, siswa masih kesulitan memahami persoalan yang berbeda contoh, siswa belum mampu mengajukan pertanyaan dan jawaban mengenai konsepkonsep matematika secara kritis. Hal ini dikarenakan model pembelajaran yang diterapkan masih cenderung didominasi oleh guru sehingga menyebabkan siswa cenderung kurang melatih kemampuan berpikir kritis matematisnya. Meski demikian, guru sudah pernah mengupayakan dengan mengganti model pembelajaran yang digunakan, akan tetapi hasilnya tidak begitu mengoptimalkan kemampuan berpikir kritis matematis, sehingga guru kembali lagi menggunakan model pembelajaran sebelumnya. 
Salah satu model pembelajaran yang diduga mampu mengembangkan kemampuan berpikir kritis matematis yaitu Process Oriented Guided Inquiry Learning (POGIL). Menurut De Gale \& Boisselle (2015) POGIL adalah suatu pembelajaran kolaboratif yang menggunakan inkuiri terbimbing dalam langkah eksplorasi, penemuan konsep, dan aplikasi. Hal ini diperkuat oleh Sen, dkk (2016); Malik, Oktaviani, Handayani, \& Chusni (2017); Rahman, Meliyana, Rifqiawati (2018) menyatakan bahwa POGIL adalah pengajaran yang berpusat pada siswa, dimana siswa berperan dengan aktif saat proses pembelajaran berlangsung, adapun proses belajarnya dilakukan secara berkelompok melalui kegiatan inquiry terbimbing dan pertanyaan yang digunakan untuk meningkatkan kemampuan berpikir kritis matematis, menyelesaikan masalah, melaporkan, metakognisi, dan tanggungjawab individu. Hanson (Rustam, dkk., 2017) menerangkan bahwa dalam model POGIL siswa belajar secara berkelompok dalam aktivitas yang dirancang untuk meningkatkan penguasaan materi dan mengembangkan kemampuan dalam proses belajar, berpikir, menyelesaikan masalah, berkomunikasi, kerja kelompok. Model POGIL menuntut siswa untuk aktif dengan memberikan berbagai peran agar siswa dapat berperan aktif saat diskusi, dengan demikian model POGIL diharapkan dapat mengembangkan kemampuan berpikir kritis matematis siswa.

Kelebihan POGIL menurut Malik, Oktaviani, Handayani, \& Chusni (2011); Zawadzki (2010) adalah 1) membantu peserta didik untuk lebih menemukan sendiri pengetahuannya; 2) mudah diterapkan pada semua jenjang pendidikan; 3) membantu peserta didik dalam meningkatkan keterampilan proses, bertanya, dan mengkomunikasikan pengetahuan; 4) dapat menjangkau materi pelajaran dalam cakupan yang luas; dan 5) dapat mengembangkan kemampuan siswa dalam problem solving. Selain kelebihan, kekurangan POGIL (Malik, Oktaviani, Handayani, \& Chusni (2011); Zawadzki, 2010) adalah 1) sulitnya mengalokasikan waktu dengan tepat; 2) sulit dilaksanakan apabila sarana penunjang seperti buku paket tidak disediakan di sekolah; dan 3 ) pembelajaran tidak akan efektif apabila dilaksanakan pada kelas yang sulit diarahkan.

Langkah-langkah pembelajaran melalui model POGIL meliputi: 1) Orientasi (Orientation), guru mempersiapkan segala sesuatu yang dibutuhkan dan dapat mendukung terjadinya proses pembelajaran di kelas. Guru mengkondisikan keadaan siswa di dalam kelas. Selanjutnya, guru memberikan motivasi dan minat belajar siswa. 2) Eksplorasi (Exploration), guru membimbing pembentukan kelompok dengan empat atau lima kelompok dimana anggota kelompok mempunyai peran masing-masing, kemudian diberikan LKPD kepada setiap kelompok sebagai bahan diskusi. Apabila dalam satu kelompok terdapat lima anggota, maka ada dua anggota yang memiliki peran sama. Pada setiap pertemuan, pembagian peran setiap siswa harus berbeda-beda agar siswa merasakan segala peran yang ada. Di dalam LKPD tersebut terdapat beberapa pertanyaan yang akan memandunya pada proses untuk mengeksporasi model. 3) Penemuan konsep atau pembentukan konsep (concept invention or concept formation), pada tahap ini siswa diberi serangkaian pertanyaan pada LKPD yang mengarah pada penemuan konsep untuk membantu siswa menemukan konsep yang sedang mereka cari. 4) Aplikasi (Application), guru memerintahkan siswa untuk mengerjakan LKPD. Agar 
kemampuan siswa meningkat, maka guru memerintahkan siswa untuk mengaplikasikan konsep yang telah ditemukannya pada soal dengan konteks baru. Hasil diskusi dicatat agar setiap kelompok mempunyai arsip hasil diskusi untuk di presentasikan. 5) Penutup (Closure), pada tahap terakhir, guru meminta spoken person sebagai perwakilan kelompok untuk mempresentasikan hasil diskusi. Kemudian, bersama siswa mengkonfirmasi jawaban tersebut. Di akhir pembelajaran strategi analys atau reflektor memandu pengisian lembar refleksi proses pembelajaran, pengisian lembar tersebut berdasarkan masukan dari teman-teman sekelompoknya. Selain itu, masing-masing anggota kelompok mengisi lembar penilaian kinerja atas keikutsertaan teman satu kelompoknya selama diskusi berlangsung. Berdasarkan latar belakang tersebut, tujuan dari penelitian ini adalah untuk menganalisis pengaruh model Process Oriented Guided Inquiry Learning (POGIL) terhadap kemampuan berpikir kritis matematis siswa.

\section{Metode Penelitian}

Penelitian ini merupakan eksperimen semu. Waktu pelaksanaan adalah pada semester genap tahun ajaran 2018/2019. Populasi dalam penelitian ini adalah seluruh siswa kelas VIII SMP N 2 Kemangkon. Teknik pengambilan sampelnya menggunakan cluster random sampling yang menghasilkan kelas VIII C sebagai kelas eksperimen yang menggunakan model POGIL dan kelas VIII B sebagai kelas kontrol yang menggunakan model pembelajaran konvensional. Desain Penelitian yang digunakan adalah Post test-Only Control Design. Pada desain penelitian ini terdapat dua kelompok yaitu kelompok eksperimen dan kelompok kontrol. Kelompok eksperimen (E) diberikan perlakuan (X) yaitu menggunakan model POGIL, sedangkan pada kelompok kontrol (K) tidak diberi perlakuan yaitu menggunakan model pembelajaran konvensional. Adapun desain penelitiannya sebagai berikut.

Tabel 1. Desain penelitian

\begin{tabular}{ccc} 
Kelompok & Perlakuan & Instrumen \\
\hline $\mathrm{E}$ & $\mathrm{X}$ & 0 \\
\hline $\mathrm{K}$ & & 0
\end{tabular}

Keterangan :

E : Kelompok Eksperimen

$\mathrm{K}$ : Kelompok Kontrol

$\mathrm{X}$ : Perlakuan (treatment) menggunakan model POGIL

0 : Pemberian Posttest kemampuan berpikir kritis siswa 


\section{Hasil dan Pembahasan}

Statistik Deskriptif

Tabel 2. Hasil Statistik Deskriptif

\begin{tabular}{|l|r|r|r|r|r|}
\hline & N & Minimum & Maximum & Mean & Std. Deviation \\
\hline Posttest_Kontrol & 30 & 31.48 & 71.15 & 48.5073 & 12.06568 \\
Posttest_Eksperimen & 30 & 36.54 & 78.85 & 61.4077 & 12.99310 \\
Valid N (listwise) & 30 & & & & \\
\hline
\end{tabular}

Berdasarkan tabel 2 perolehan nilai rata-rata post test kemampuan berpikir kritis kelas eksperimen lebih tinggi dibandingkan nilai rata-rata post test kemampuan berpikir kritis matematis pada kelas kontrol dengan selisih 12,9004. Hasil perhitungan post test kemampuan berpikir kritis matematis diperoleh nilai maksimum pada kelas eksperimen 78,85 dan kelas kontrol 71,15 sedangkan nilai minimum pada kelas eksperimen yaitu 36,54 dan kelas kontrol yaitu 31,48. Dengan nilai rata-rata kelas eksperimen yaitu 61,4077 sedangkan kelas kontrol yaitu 48,5073. Dari penjabaran di atas dapat diduga bahwa nilai rata-rata kemampuan berpikir kritis matematis pada kelas eksperimen yang menerapkan model POGIL lebih tinggi daripada kelas kontrol yang menggunakan model pembelajaran konvensional

Uji Normalitas

Dengan bantuan SPSS 23 normalitas data ditentukan dengan uji Kolmogorov Smirnov. Hipotesis :

$H_{0} \quad$ : data berdistribusi normal

$H_{1} \quad$ : data tidak berdistribusi

Data dikatakan berdistribusi normal apabila nilai sig. $>\alpha$ yang ditentukan, yaitu 0,05 .

Tabel 3. Hasil uji normalitas kemampuan berpikir kritis matematis

\begin{tabular}{lccccc}
\hline & \multicolumn{3}{c}{ Kests of Normality } \\
& Statistic & df & Sig. & Statistic & Sig. \\
\hline posttestkontrol & .109 & 30 & $\mathbf{. 2 0 0}^{*}$ & .943 & .112 \\
\hline posttesteksperimen & .129 & 30 & $\mathbf{. 2 0 0}^{*}$ & .931 & .052
\end{tabular}

Tabel 3 menunjukkan bahwa nilai signifikansi pada kolmogorov smirnof baik kelas eksperimen mauupun kelas kontrol pada kelas eksperimen adalah 0,200. Artinya, nilai Sig $>\alpha=0,05$, sehingga $H_{o}$ diterima. Dengan kata lain, data kemampuan berpikir kritis kelas eksperimen dan kelas kontrol berdistribusi normal. 


\section{Uji Homogenitas}

Uji yang digunakan untuk menentukan homogenitas data adalah Test of Homogenity Of Variance Uji levene dengan bantuan SPSS 23. Hipotesisnya sebagai berikut.

$H_{0}=\sigma_{p}^{2}=\sigma_{k}^{2}$ (Variansi skor kemampuan berpikir kritis berasal dari populasi yang homogen).

$H_{1}=\sigma_{p}^{2} \neq \sigma_{k}^{2}$ (Variansi skor kemampuan berpikir kritis tidak berasal dari populasi yang homogen).

Variansi skor kemampuan berpikir kritis dikatakan berasal dari populasi yang homogen apabila nilai sig. $>\alpha$ yang ditentukan, yaitu 0,05 . Hasil uji homogenitasnya sebagai berikut.

Tabel 4. Hasil Uji Homogenitas Skor Kemampuan Berpikir Kritis Matematis Siswa

\section{Test of Homogeneity of Variances}

\begin{tabular}{r|rrr|r|r}
\multicolumn{1}{l}{$\begin{array}{l}\text { Posttest } \\
\text { Levene Statistic }\end{array}$} & df1 & & df2 & \multicolumn{1}{l}{ Sig. } \\
\hline, 116 & & 1 & & 58 &, 735 \\
\hline
\end{tabular}

Berdasarkan tabel 4, nilai sig Levene Statistic $=0,735>\alpha=0,05$. Jadi, dapat disimpulkan bahwa $H_{0}$ diterima. Artinya, variansi skor kemampuan berpikir kritis berasal dari populasi yang homogen.

\section{Uji Hipotesis}

Setelah uji prasyarat terpenuhi, yaitu normalitas dan homogenitas, uji analisis dilanjutkan dengan uji hipotesis. Uji hipotesis yang digunakan adalah independent $t$ test dengan bantuan SPPS 23. Hipotesisnya sebagai berikut.

$H_{0}=\mu_{p} \leq \mu_{k}$ (Rata-rata skor kemampuan berpikir kritis matematis siswa yang mengikuti pembelajaran dengan model POGIL tidak lebih baik atau sama dengan siswa yang mengikuti pembelajaran konvensional).

$H_{1}=\mu_{p}>\mu_{k} \quad$ (Rata-rata skor kemampuan berpikir kritis matematis siswa yang mengikuti pembelajaran dengan model POGIL lebih baik dengan siswa yang mengikuti pembelajaran konvensional).

Keterangan:

$\mu_{p}$ : Rata-rata kemampuan berpikir kritis matematis siswa yang mengikuti model POGIL.

$\mu_{k}$ : Rata-rata kemampuan berpikir kritis matematis siswa yang mengikuti pembelajaran konvensional

$H_{0}$ ditolak jika $\frac{\text { sig. }}{2}<\alpha=0,05$. 
Hasil uji hipotesis ada pada tabel 5 berikut.

Tabel 5. Hasil Uji Hipotesis

\begin{tabular}{|c|c|c|c|c|c|c|c|c|c|c|}
\hline \multicolumn{11}{|c|}{ Independent Samples Test } \\
\hline & & \multicolumn{2}{|c|}{$\begin{array}{c}\text { Levene's Test } \\
\text { for Equality of } \\
\text { Variances }\end{array}$} & \multicolumn{7}{|c|}{ t-test for Equality of Means } \\
\hline & & \multirow[b]{2}{*}{$F$} & \multirow[b]{2}{*}{ Sig. } & \multirow[b]{2}{*}{$\mathrm{T}$} & \multirow[b]{2}{*}{ df } & \multirow{2}{*}{$\begin{array}{l}\text { Sig. (2- } \\
\text { tailed) }\end{array}$} & \multirow{2}{*}{$\begin{array}{c}\text { Mean } \\
\text { Differenc } \\
\mathrm{e}\end{array}$} & \multirow{2}{*}{$\begin{array}{c}\text { Std. } \\
\text { Error } \\
\text { Differenc } \\
\mathrm{e} \\
\end{array}$} & \multicolumn{2}{|c|}{$\begin{array}{l}95 \% \text { Confidence } \\
\text { Interval of the } \\
\text { Difference }\end{array}$} \\
\hline & & & & & & & & & Lower & Upper \\
\hline \multirow[t]{2}{*}{ Posttest } & $\begin{array}{l}\text { Equal variances } \\
\text { assumed }\end{array}$ &, 116 & ,735 & $-3,985$ & 58 &, 000 & 12,90033 & 3,23729 & $-19,38047$ & $-6,42020$ \\
\hline & $\begin{array}{l}\text { Equal variances } \\
\text { not assumed }\end{array}$ & & & $-3,985$ & $\begin{array}{r}57,68 \\
5\end{array}$ &, 000 & $12,90033^{-}$ & 3,23729 & $-19,38122$ & $-6,41944$ \\
\hline
\end{tabular}

Berdasarkan uji hipotesis diketahui bahwa nilai sig. (2-tailed) pada equal varinces assumed adalah 0,000, sehingga didapatkan nilai $\frac{\text { sig. }}{2} \leq 0,05$. Artinya, $H_{0}$ ditolak. Jadi, rata-rata skor kemampuan berpikir kritis siswa yang menerapkan model POGIL lebih baik daripada kemampuan berpikir kritis siswa yang menerapkan model pembelajaran konvensional, dengan kata lain model POGIL berpengaruh terhadap kemampuan berpikir kritis siswa.

Berdasarkan hasil post test kemampuan berpikir kritis matematis siswa pada kelas eksperimen dan kelas kontrol menunjukkan bahwa nilai rata-rata kemampuan berpikir kritis siswa pada kelas eksperimen yang menerapkan model POGIL sebesar 61,41 lebih tinggi dibandingkan dengan rata-rata kelas kontrol yang menerapkan model pembelajaran konvensional yaitu sebesar 48,5, sehingga model POGIL berpengaruh terhadap kemampuan berpikir kritis matematis siswa. Hal ini dikarenakan dalam model POGIL lebih mengedepankan pendekatan proses pembelajaran yang berpusat pada siswa dengan mendorong partisipasi siswa agar lebih aktif dalam kelas.

Penerapan model POGIL dapat membantu mengembangkan kemampuan berpikir kritis matematis siswa. Hal tersebut dikarenakan dalam pembelajaran siswa dituntut untuk lebih memahami materi yang sedang diajarkan, mampu berpikir dalam menyelesaikan masalah, mampu berkomunikasi dengan baik, dan setiap siswa dituntut untuk berperan aktif dengan memberikan berbagai peran saat diskusi berlangsung. Langkah-langkah model POGIL dapat memfasilitasi siswa untuk mengembangkan kemampuan berpikir kritis matematis.

Tahap pertama POGIL adalah orientasi (orientation), dalam tahap ini guru, mengkondisikan siswa didalam kelas serta memberikan motivasi dan rangsangan untuk memusatkan perhatian pada topik materi bangun ruang sisi datar. Pada saat memotivasi guru menyuruh siswa untuk 
membaca dan memahami materi yang ada dibuku paket, sehingga dapat mengembangkan kemampuan berpikir kritis matematis pada indikator menganalisis. Motivasi diberikan agar siswa dapat mengetahui pembelajaran yang akan dilakukan. Menurut Kamalludin (2017) manfaat dari motivasi sendiri dapat memberikan pengaruh positif pada proses dan hasil belajar yaitu dapat menciptakan suasana belajar yang baik, sehingga proses belajar di kelas akan menjadi lebih aktif, siswa akan menjadi aktif dalam bertanya dan menjawab pertanyaan, sehingga akan menumbuhkan rasa percaya diri siswa. Selain itu, guru memberikan rangsangan pada awal pembelajaran, dimana guru memberikan pertanyaan pada siswa untuk mencari contoh bangun ruang sisi datar yang ada di dalam kelas, sehingga dapat mengembangkan kemampuan berpikir kritis matematis pada indikator menganalisis dimana siswa dapat memberikan contoh bangun ruang sisi datar dengan mengidentifikasi sifat-sifat bangun ruang sisi datar.

Tahap kedua POGIL adalah Eksplorasi (Exploration), guru membimbing siswa untuk membentuk kelompok yag berisi 4-5 siswa, di mana anggota kelompok mempunyai peran masing-masing diantaranya yaitu Manajer (The Manager), Perekam (Recorder), Analis strategi (Strategy Analyst), Juru bicara (Spokenperson). Masing-masing peran memiliki tugas, manager (The Manager) bertugas untuk menjaga kelompok dan berusaha memastikan bahwa setiap anggota berperan serta dalam pengerjaan tugas kelompok. Seorang manager harus mampu bertanggungjawab dalam anggota kelompoknya, sehingga seorang manager mampu mengembangkan sikap self confidence dalam indikator bertanggung jawab. Bila seorang manager mampu mengatur jalannya diskusi dengan baik maka ia dapat melatih sikap kerjasama yang baik. Hal ini diperkuat oleh Muhammad (2016) bahwa seorang manager harus mampu bekerjasama dengan baik dan memiliki peran sebagai perencana, pengelola, dan pengontrol jalannya kegiatan. Perekam (Recorder) atau siswa yang berperan sebagai notulen bertugas untuk mempersiapkan hasil diskusi. Analis strategi (Strategy Analyst) tugasnya yaitu merefleksikan apa yang sudah dipelajari dan yang belum dipahami selama kegiatan diskusi. Juru bicara (Spokenperson) tugasnya adalah sebagai perwakilan kelompok yang menyajikan hasil diskusi kelompok di depan kelas. Adanya kerja kelompok dapat memberikan kesempatan kepada peserta didik agar lebih aktif berinteraksi sesama teman.

Tahap ketiga POGIL adalah penemuan konsep atau pembentukan konsep (Concept invention or concept formation). Di dalam LKPD yang sudah dibagikan terdiri dari lembar aktivitas dan lembar masalah berisi serangkaian pertanyaan yang akan memandu siswa pada proses untuk menemukan sebuah konsep tentang luas permukaan dan volume bangun ruang sisi datar. Pada tahap ini, guru membimbing peserta didik untuk mengamati alat peraga yang telah dibagikan dan membuatnya menjadi sebuah jaring-jaring. Dari kegiatan tersebut siswa berdiskusi bersama kelompoknya dengan mengidentifikasi apa nama bangun tersebut, bagaimana sifatsifat bangun ruang sisi datar tersebut, sehingga pada tahap ini dapat mengembangkan kemampuan berpikir kritis matematis dalam indikator menganalisis dan mensintesis.

Tahap keempat POGIL adalah Aplikasi (Application), pada tahap ini guru memerintah siswa untuk mengerjakan lembar kegiatan pada masalah 1 dan 2. Setelah itu guru memerintahkan 
siswa untuk mencatat hasil diskusi sehingga dapat dijadikan arsip saat presentasi. Pada tahap ini siswa akan bekerja sama dalam berdiskusi untuk menyelesaikan sebuah persoalan yang ada pada masalah 1 dan 2, dimana siswa akan menggabungkan konsep yang didapatkannya untuk mengerjakan soal yang ada di masalah 1 dan 2 , kegiatan tersebut termasuk indikator mensintesis yaitu menggabungkan konsep untuk ditemuin penyeesaian masalah, sehingga pada ini akan dapat mengembangkan kemampuan berpikr kritis matematis dalam indikator menganalisis dan mensintesis. Diskusi dapat memberikan ruang bagi siswa untuk mencari informasi bersama teman sekelompoknya terkait tugas yang sedang dikerjakan dan memunculkan terjadinya proses bertukar pemikiran antar siswa yang nantinya dapat menambah informasi yang akan digunakan untuk mencari solusi dari masalah yang diberikan. Hal ini sejalan dengan definisi berpikir ktitis matematis menurut (Yildirm \& Ozkaraman, 2011) bahwa kemampuan berpikir kritis matematis merupakan proses mencari, memperoleh, mengevaluasi, menganalisis informasi sebagai panduan untuk mengembangkan pemikiran seseorang, sehingga kegiatan diskusi dapat mengembangkan kemampuan berpikir kritis matematis dalam indikator menganalisis, mensintesis, menyimpulkan dan mengevaluasi dalam indikator berani mengemukakan pendapat, rasional, dan objektif. Aktivitas siswa terlihat pada gambar 1. di bawah ini.

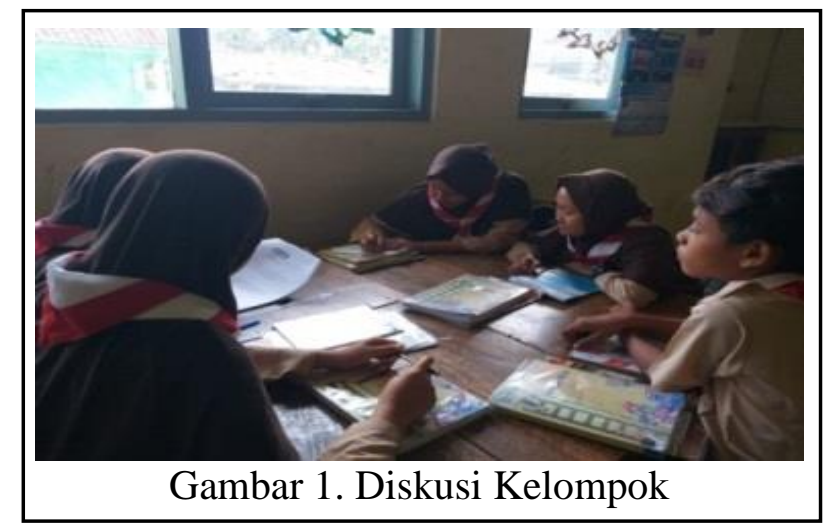

Tahap kelima POGIL adalah penutup (Closure), pada tahap ini guru meminta spoken person yang dipilih secara acak untuk mempresentasikan hasil diskusinya seperti pada gambar di bawah ini.

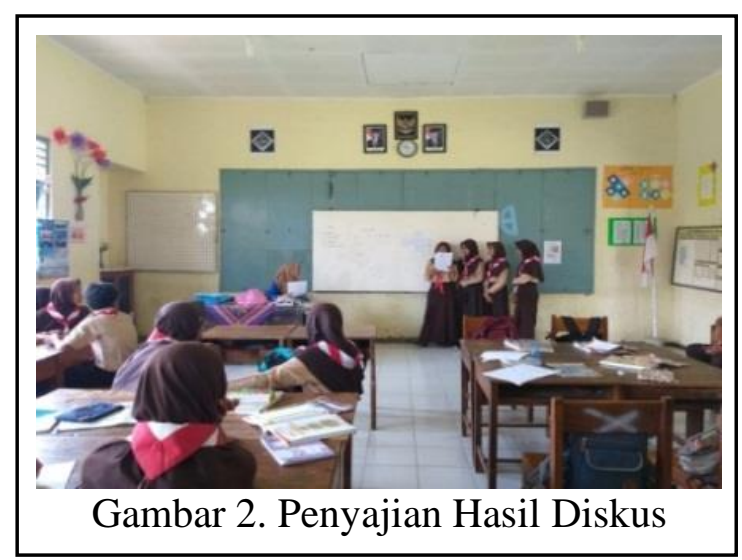

(C)2019 by Department of Mathematics Education, UMP, Purwokerto, Indonesia p-ISSN 2477-409X, e-ISSN: 2549-9084 and website: http://jurnal nasional.ump.ac.id/index.php/alphamath/ 
Presentasi dapat melatih tingkat kepercayaan diri siswa, dimana siswa berani mengemukakan pendapatnya dan mampu mengkomunikasikan pendapatnya dengan baik. Hal ini sejalan dengan pendapat Marpaung (2018) bahwa presentasi dapat menumbuhkan rasa percaya diri karena di dalam proses pembelajaran tersebut memungkinkan kemunculan berbagai kemampuan seperti kemampuan menganalisis masalah, berpendapat, serta kemampuan mempertahankan pendapatnya. Seorang spoken person akan menyampaikan hasil diskusi kelompoknya, setelah itu guru bersama kelompok lain akan mengonfirmasi hasil diskusi kelompok tersebut, sehingga akan adanya proses menyimpulkan dan mengevaluasi apakah hasil diskusi yang dipresentasikan dapat diterima atau tidak oleh kelompok lain, dan siswa dapat menyimpulkan terkait hasil diskusinya yaitu menyimpulkan rumus apa saja yang digunakan dalam mencari luas permukaan dan volume dari beberapa bangun ruang sisi datar. Dengan adanya presentasi akan menyebabkan siswa jauh lebih aktif, dan siswa jauh lebih percaya diri bila dilatih secara terus menerus. Di akhir pembelajaran, reflektor memandu pengisian lembar refleksi proses pembelajaran. Berdasarkan uraian di atas maka pada tahap ini dapat mengembangkan kemampuan berpikir kritis matematis pada indikator menyimpulkan dan mengevaluasi.

Berbeda dengan kelas yang di berikan model pembelajaran konvensional, siswa jauh lebih pasif daripada kelas yang diberikan model POGIL. Pada awal pembelajaran, guru memberikan motivasi terkait manfaat mempelajari bangun ruang sisi datar, yang kemudian dilanjutkan dengan pemberian materi kepada siswa. Pada pembelajaran konvensional guru lebih berperan sebagai pemberi informasi secara langsung dan siswa hanya mendengarkan materi yang disampaikan guru. Guru langsung memberikan materi yang baru setelah pemberian motivasi, sehingga siswa kurang memiliki kesempatan untuk melatih kemampuan berpikir kritisnya pada indikator menganalisis dimana seharusnya siswa mampu memberikan contoh terkait bangun ruang sisi datar yang ada dilingkungan sekitarnya.

Kemudian pada saat kegiatan inti guru hanya memberikan materi dengan cara menuliskan rumus-rumus terkait bangun ruang sisi datar di papan tulis, kemudian menjelaskannya di depan siswa, setelah itu siswa diberikan soal latihan individu yang kemudian di bahas secara bersama-sama, siswa hanya mendengarkan penjelasan dari guru saja. Kemudian kemampuan berpikir kritis matematis siswa cenderung kurang dilatih karena minimnya kegiatan dalam menganalisis suatu permasalahan, beberapa siswa belum mampu memberikan jawaban saat menjawab soal yang berbeda dengan contoh yang diberika oleh guru. Saat diberi pertanyaan seputar materi yang sedang diajarkan siswa tidak mampu menjawab dengan baik. Hal ini disebabkan siswa tidak memiliki rasa percaya diri yang tinggi dikarenakan takut salah ketika menjawab sebuah pertanyaan, begitu juga siswa hanya mampu menjawab soal yang setipe dengan contoh soal yang diberikan oleh guru sehingga saat menjumpai soal yang lain atau berbeda contoh siswa tidak mampu menjawabnya dengan baik. Berdasarkan pemaparan di atas, maka dapat disimpulkan bahwa model POGIL berpengaruh terhadap kemampuan berpikir kritis matematis siswa kelas VIII SMP N 2 Kemangkon. Setelah dilakukan pembelajaran dengan beberapa pertemuan pada kedua kelas, peneliti mengadakan post test untuk mengetahui kemampuan berpikir kritis matematis. 


\section{Simpulan}

Berdasarkan penelitian yang telah dilakukan oleh peneliti maka dapat disimpulkan bahwa model POGIL (Process Oriented Guided Inquiry Learning) berpengaruh terhadap kemampuan berpikir kritis siswa.

\section{Daftar Pustaka}

De Gale, S., \& Boisselle, L. N. (2015). The effect of POGIL on academic performance and academic confidence.

Ennis, R. (1991). Critical thinking: A streamlined conception. Teaching philosophy, 14(1), 524.

Ennis, R. H. (2011). The nature of critical thinking: An outline of critical thinking dispositions and abilities. University of Illinois, 2-4.

Fahmy, A. F. R., Wardono, W., \& Masrukan, M. (2018, February). Kemampuan Literasi Matematika dan Kemandirian Belajar Siswa Pada Model Pembelajaran Rme Berbantuan Geogebra. In PRISMA, Prosiding Seminar Nasional Matematika (Vol. 1, pp. 559-567).

Haryani, D. (2011). Pembelajaran matematika dengan pemecahan masalah untuk menumbuhkembangkan kemampuan berpikir kritis siswa. In Prosiding Seminar Nasional Penelitian, Pendidikan dan Penerapan MIPA, FMIPA, UNY pada (Vol. 14, pp. 121-26).

Johnson, E. B. (2007). Contextual teaching and learning: Menjadikan kegiatan belajar mengajar mengasyikkan dan bermakna. Bandung: Mizan Learning Center.

Kamaluddin, M. (2017). Pengaruh Motivasi Belajar Terhadap Prestasi Belajar Matematika dan Strategi untuk Meningkatkannya. In Seminar Matematika Dan Pendidikan Matematika UNY 2017, ISBN. 978-602-73403-2 (Vol. 9).

Malik, A., Oktaviani, V., Handayani, W., \& Chusni, M. M. (2017). Penerapan Model Process Oriented Guided Inquiry Learning (POGIL) Untuk meningkatkan Keterampilan Berpikir Kritis Peserta Didik. Jurnal Penelitian \& Pengembangan Pendidikan Fisika, 3(2), 127-136.

Marpaung, D. (2018).'Penerapan Metode Diskusi dan Presentasi untuk Meningkatkan Minat dan Hasil Belajar Siswa di Kelas XI IPS-1 SMA Negeri Bagan 1 Sinembah". School Education Journal, 8, (4)

Muhammad, M. (2017). Pengaruh Motivasi dalam Pembelajaran. Lantanida Journal, 4(2), 87-97.

Paul, R \& Elder, L. (2007). "Critical Thinking Competency Standars". Foundation for Critical Thinking Press. www.criticalthinking.org

Prihatiningsih, dkk. (2016). "Kemampuan Berpikir Kritis Siswa SMP Pada Materi Klasifikasi Makhluk Hidup". Pros. Semnas Pend. IPA Pascasarjana UM, 1

Rahman, A., Meliyana, M., \& Rifqiawati, I. (2018). Pengaruh Model Pembelajaran Process Oriented Guided Inquiry Learning (Pogil) Terhadap Kemampuan Komunikasi Siswa 
Pada Subkonsep Urinaria Kelas Xi Di Ma. Bioedukasi (Jurnal Pendidikan Biologi), 9(2), 132-143.

Sen, S., dkk. (2016). "High School Students Views about Process Oriented Guided Inquiry Learning (POGIL)". The Turkish Online Journal of Educations Technology

Siregar, N. R. (2017). Persepsi siswa pada pelajaran matematika: studi pendahuluan pada siswa yang menyenangi game. Prosiding Temu Ilmiah Nasional X Ikatan Psikologi Perkembangan Indonesia, 1 .

Yildirim, B., \& Ozkahraman, S. (2011). Critical thinking in nursing process and education. International journal of humanities and social science, 1(13), 257-262.

Zawadzki, R. (2010). Is process oriented guided inquiry learning (POGIL) suitable as a teaching method in thailand's higher education. Asian journal on education and learning, 1(2), 66-74. 